\title{
APPENDIX II. SITE SURVEY IN HATTON-ROCKALL BASIN (Sites 116 and 117)
}

\author{
D. G. Roberts, National Institute of Oceanography, Wormley, Godalming, Surrey
}

\section{REGIONAL LOCATION}

The Hatton-Rockall Basin is a part of the Rockall Plateau believed to be a continental fragment (Bullard et. $a l ., 1965)$ isolated during the polyphase spreading history of that part of the northern Atlantic Ocean. The regional structure of the plateau consists of two basement highs on which sediment is thin or absent, separated by the thick sediments of the Hatton-Rockall Basin (Roberts, 1970, 1971; Roberts et al., 1970).

\section{OBJECTIVE OF DRILL HOLE}

The thick sedimentary sequence ( 2.0 seconds two-way time) in the Hatton-Rockall Basin revealed by the original Discovery 29 profile contains five prominent reflectors (Roberts et al., 1970; Scrutton and Roberts, 1971). Reflectors 1,2 and 3 occur in a largely conformable sequence that wedges out against the more steeply dipping reflector 4 ( 0.9 second two-way time) consisting in turn of a series of hyperbolae that may be indicative of faulting.

The objective of the hole was to obtain a detailed biostratigraphy of the sediments overlying reflector 4 for data on the depositional regime and subsidence history of the plateau.

Ancillary objectives included the detection of changes in facies and paleontology of the post-reflector 4 sediments and their relation to Tertiary changes in the North Atlantic circulation. Regionally, the results would be valuable in establishing the relationship between the stratigraphictectonic history of the plateau and the polyphase spreading of the Reykjanes Ridge.

\section{SITE SURVEY (Figure 1)}

The site survey was made from Discovery (Cruise 33) between April 10-11, 1970. The survey was conducted relative to a moored (7 per cent scope) radar transponder danbuoy, and radar fixes were recorded at 10 minute intervals. Satellite and Loran C fixes were also taken and used to determine the mean position of the danbuoy. Accuracy relative to the danbuoy is estimated at \pm 0.1 n.m. and the mean position as $57^{\circ} 35.51^{\prime} \mathrm{N}, 15^{\circ} 51.94^{\prime} \mathrm{W}( \pm 0.2$ n.m. standard deviation).

The seven survey tracks were oriented ENE-WSW with diagonal tielines given by the Discovery 29 profile and the disposable sonobuoy profile. Legs 1,2 and 3 were reoccupied due to instrumental difficulties. The pattern was designed to detect any faults etc., that may have been obscured on the original Discovery profile. Seven profiles, each approximately 6 miles in length were made together with two abortive wide angle reflection profiles using disposable sonobuoys. A 3.79 meter gravity core (Station No. 7283) was taken in 1149 meters of water and also a velocimeter dip (Station No. 7282) for use in interpreting the wide angle reflection data.

\section{Topography (Figure 1)}

Depth across the survey area ranges from 605 to 625 uncorrected fathoms.

\section{Magnetic Field}

No magnetic measurements were made during the survey. Passage tracks in and out of the survey area show the field is undisturbed over the Hatton-Rockall Basin.

\section{Seismic Reflection Survey}

The seismic reflection profiling system consisted of a modified Lamont air-gun and a neutrally buoyant hydrophone array towed 600 feet astern of the ship. The signal received on the array was amplified and filtered $(30-300 \mathrm{~Hz}$ bandpass) prior to display on an 18-inch Mufax wet paper recorder set to a sweep of 4 seconds. The reflection profiles shown here (Figure 3) are photographs of the original records. A section of the Discovery 29 traverse is also shown. An isopachyte map (Figure 2) of sediments above reflector 4 was constructed from the profiles.

\section{Interpretation of Seismic Profiler Data (Figures 2 and 3)}

Reflectors 1 to 5 , which were first observed on the Discovery 29 traverse were recognizable on all traverses of the survey area. A further reflector (1a) at a depth of 0.25 second (two-way time) has been identified above reflector 1 ( 0.3 second). Reflectors 2 and 3 are located at depths of 0.6 and 0.75 seconds below the sea floor. These reflectors can be correlated across all the records but suffer minor disturbance, due possibly to minor faulting at several points (for example, at $2157 / \operatorname{Leg} 4$ ). Although there are several minor unconformities (for example, 1920/Leg 3) the sequence within 1,2 and 3 is generally conformable. Reflector 4 , the drilling objective, is overlain unconformably by these sediments and is situated at a depth of between 0.60 and 0.90 seconds (two-way time). The numerous small hyperbolae and irregular reflectors that constitute reflector 4 (and are also present in the underlying sediments) are suggestive of fracturing and minor folding. Reflector 5 consists of broader and more diffuse hyperbolae and underlies reflector 4 at a depth of 1.3 to 1.7 seconds below seabed. The depths to reflector 5 at this site preclude any penetration by the DSDP.

The apparent minor faulting evidenced by vertical discontinuities in the sedimentary sequence was observed on all legs of the survey and also on the original Discovery 29 profile necessitating, therefore, a careful appraisal of fault trends. Some of the discontinuities correlate closely 


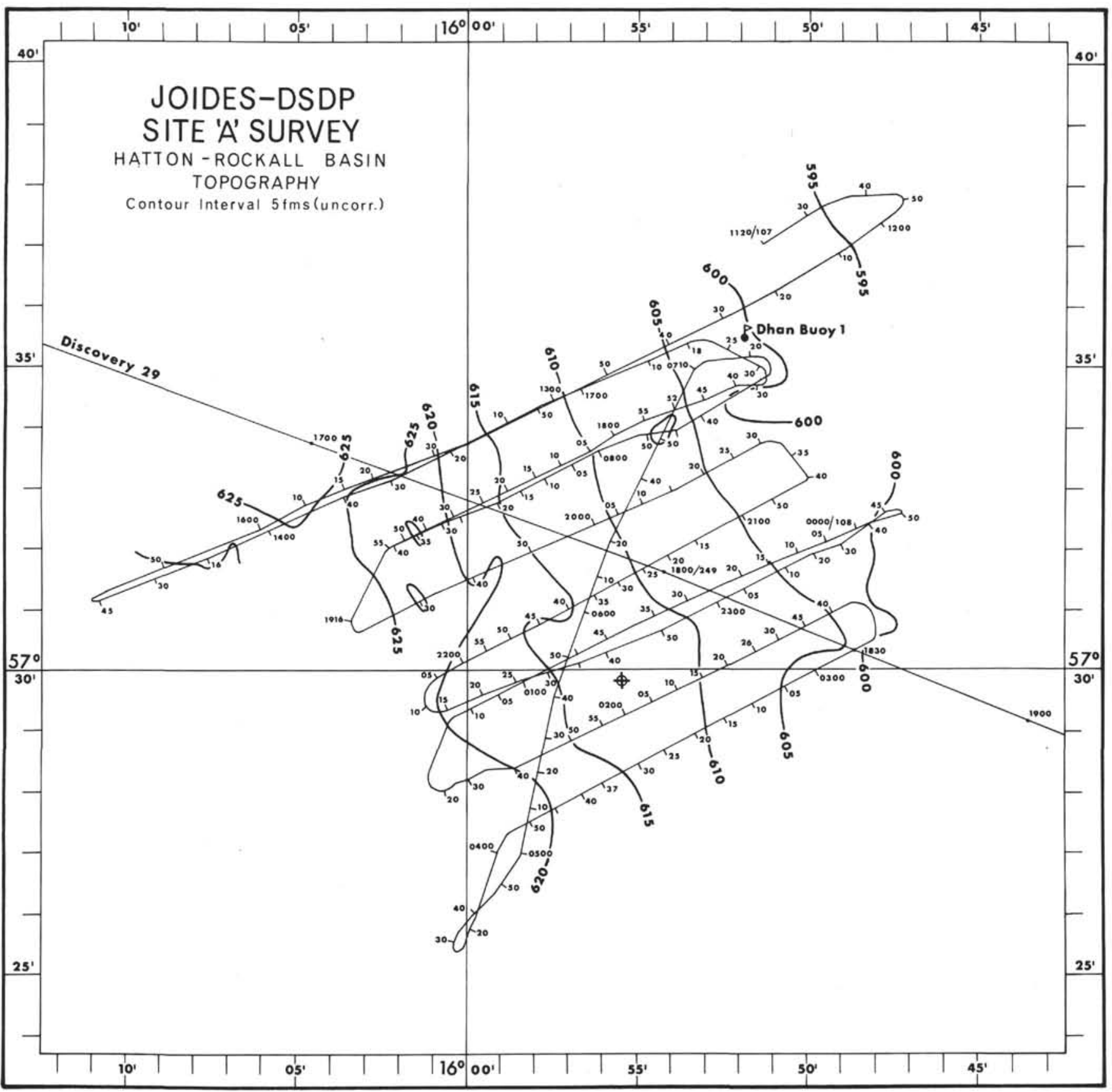

Figure 1. Hatton-Rockall Basin Site survey and bathymetry. DSDP Site 116.

with depressions in the sea floor and may represent either syndepositional faulting or channels, due to both differential deposition and erosion. Although detailed maps of depression and fault location were drawn to resolve both trend and correlation between 'faults' and channels, it is evident that the discontinuities cannot all be correlated with the sea floor depressions. The depressions appear to trend sinuously and discontinuously in a NNE-SSW direction while the faults are also more numerous (and perhaps associated) with the increase in dip of reflector 4. On these grounds, the isopachyte map shows that the faults trend broadly E-W although the possibility of a conjugate pattern may exist also.
The sequence overlying reflector 4 is largely conformable, and only one significant unconformity has been detected (at 0257/Leg 7) within it. The complete sequence is not everywhere present above reflector 4 since elevations in reflector 4 locally cut out reflector 3 , so that sediments in the interval 3-4 are more completely preserved in depressions in reflector 4 . In such cases the maximum stratigraphic sequence could only be sampled by drilling to a depth of 0.90 second compared to 0.60 second on the elevation in reflector 4 . If an average velocity of sound in sediments is assumed to be $2 \mathrm{~km} \mathrm{sec}^{-1}$, this gives comparative drilling depths of 0.90 kilometer and 0.60 kilometer. 


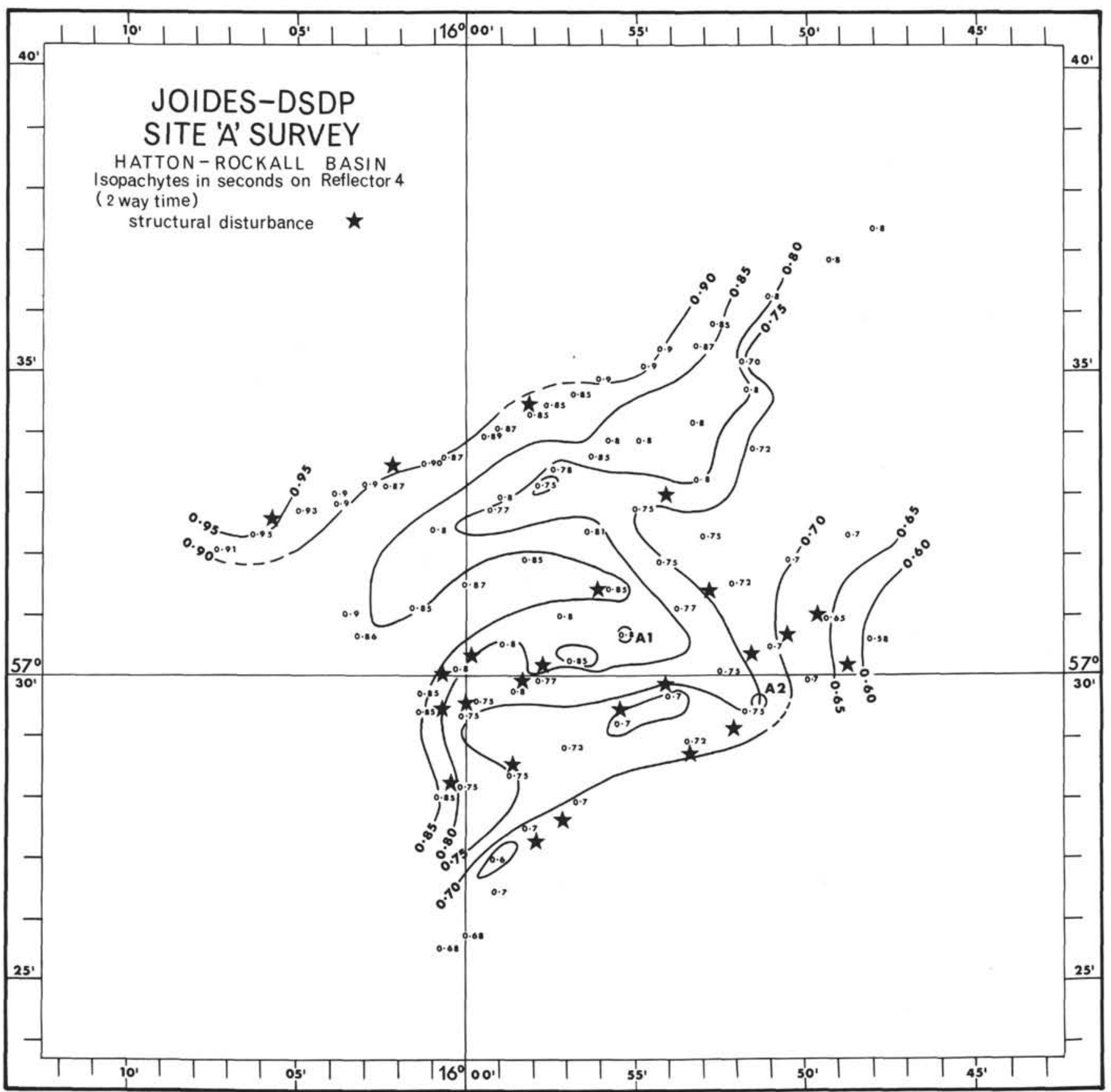

Figure 2. Hatton-Rockall Basin Site Survey. 
LEG 1a

1550/107-1710/107

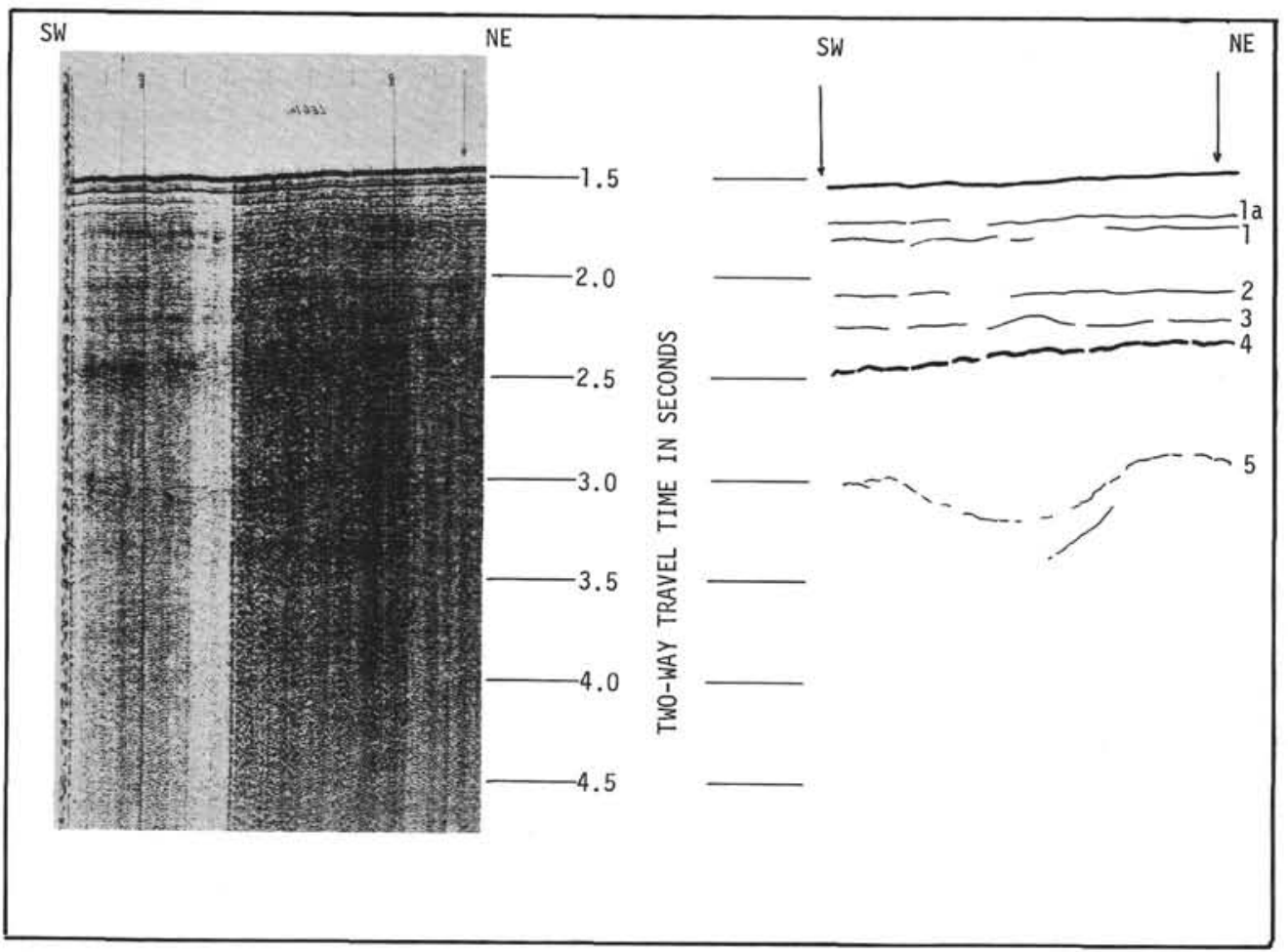

LEG 2

$0730 / 108-0830 / 108$

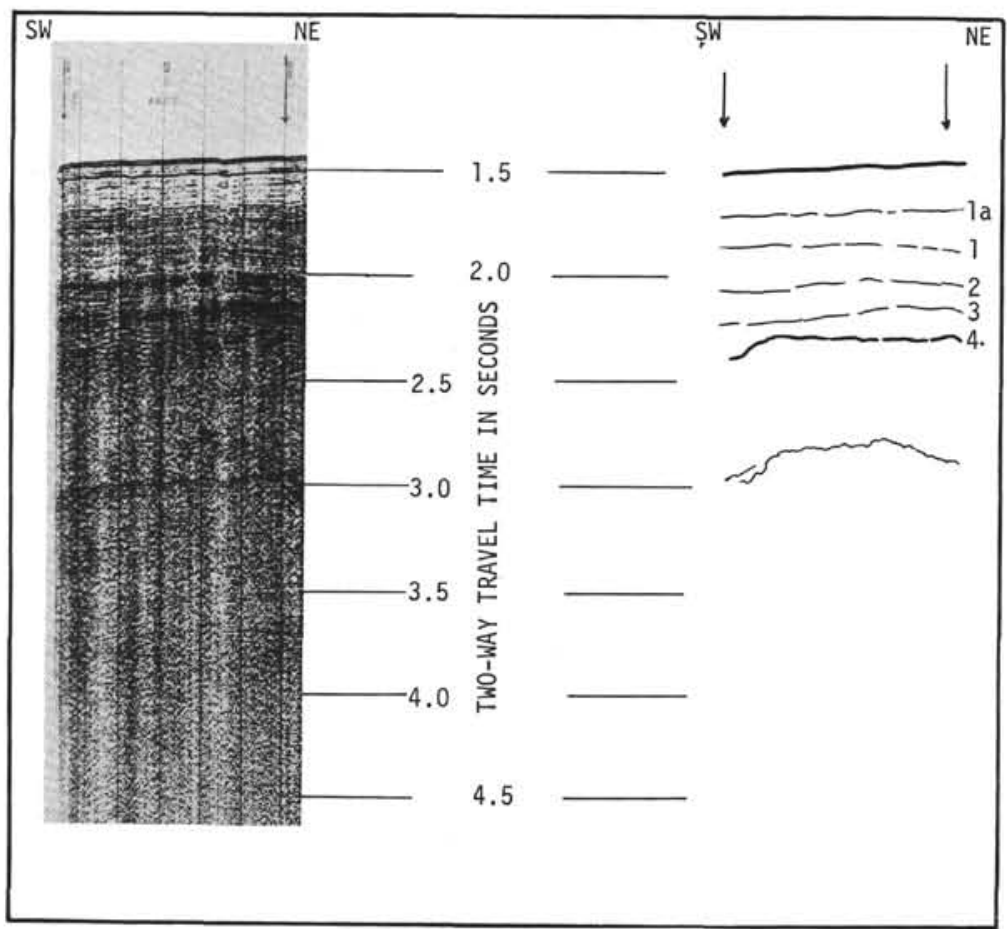

Figure 3. Reflection profiles across site and line drawings of profiles. 
LEG 3

$1920 / 107-2030 / 107$

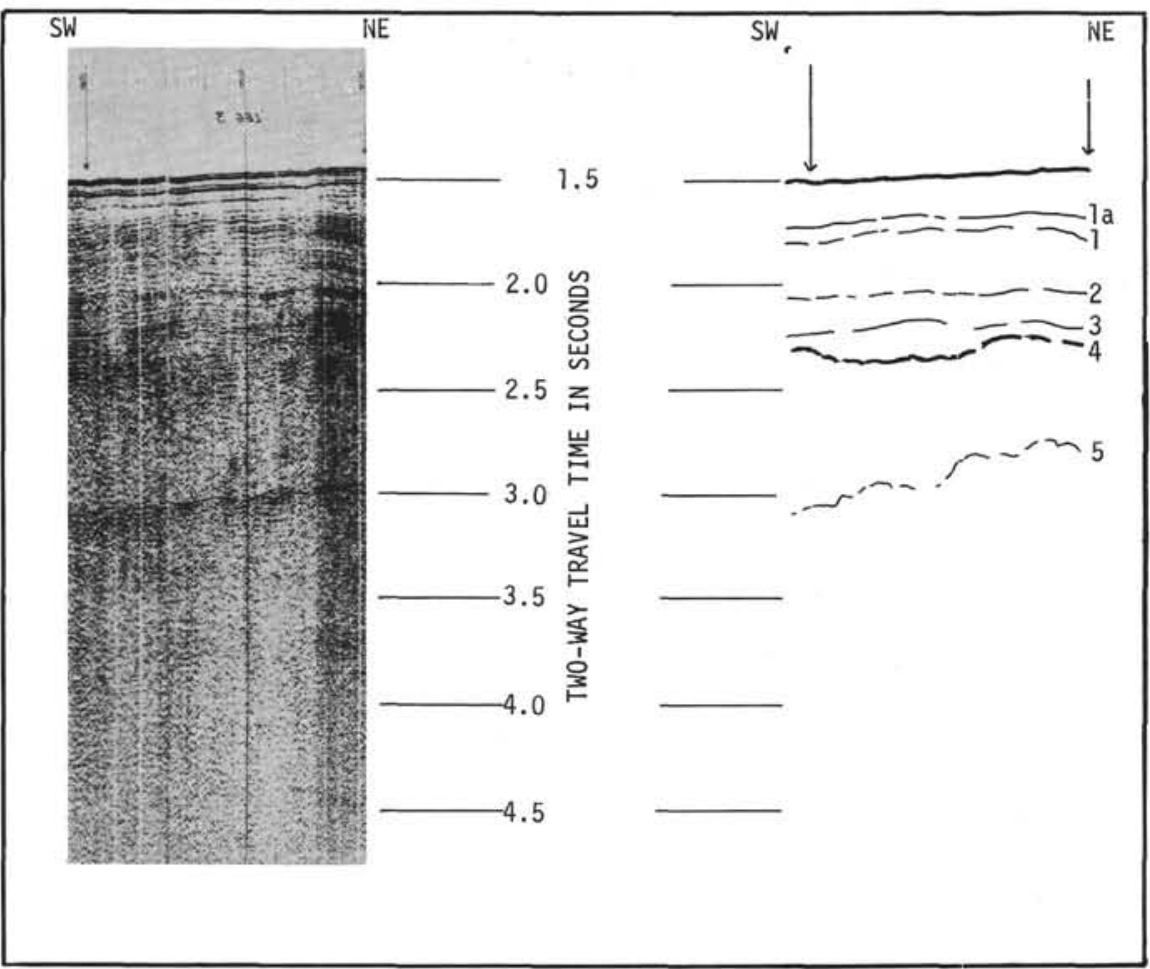

LEG 4

2108/107-2208/107

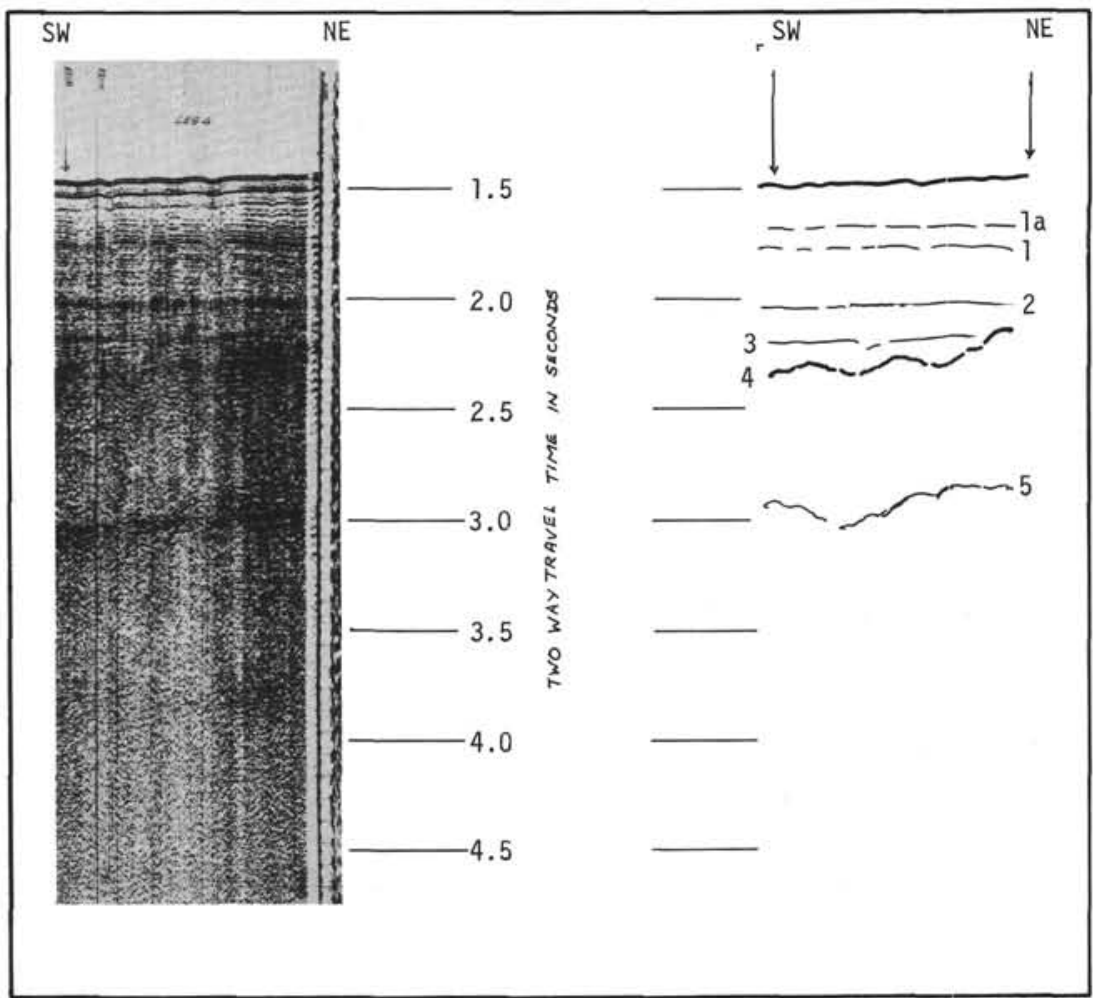

Figure 3. (Continued) 
2350/107-0112/108

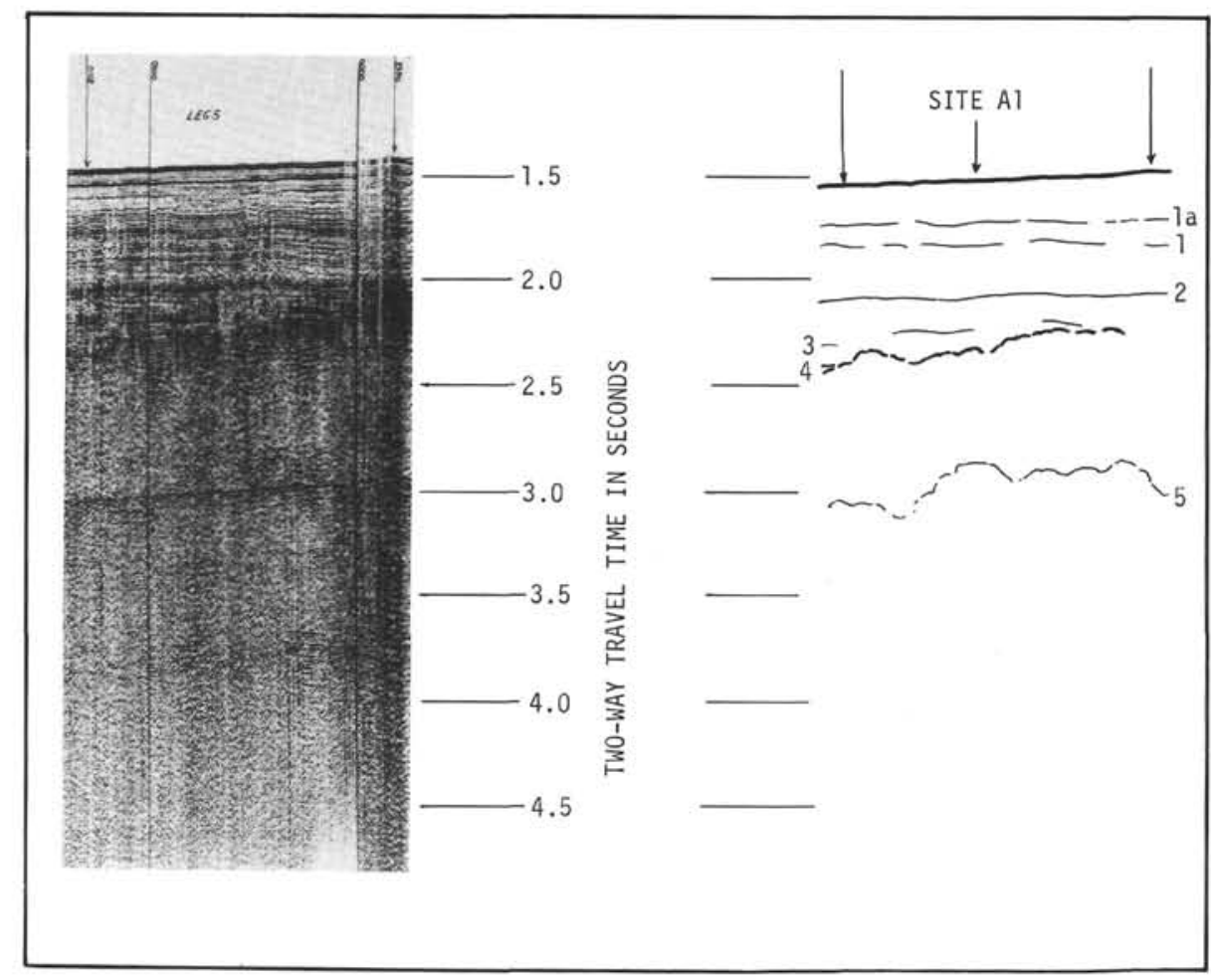

LEG 6

$0130 / 108-0242 / 108$

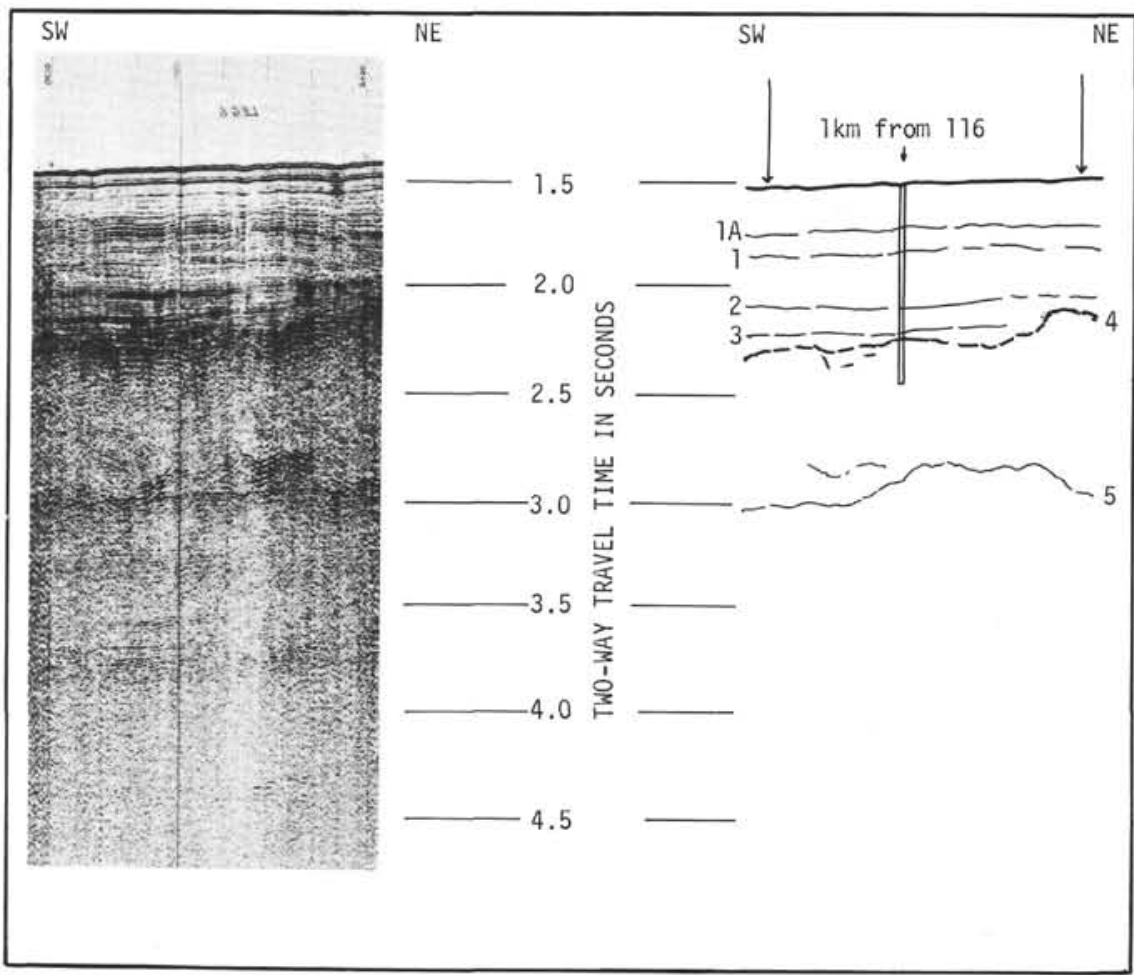

Figure 3. (Continued) 
LEG 7

$0257 / 108-0352 / 108$

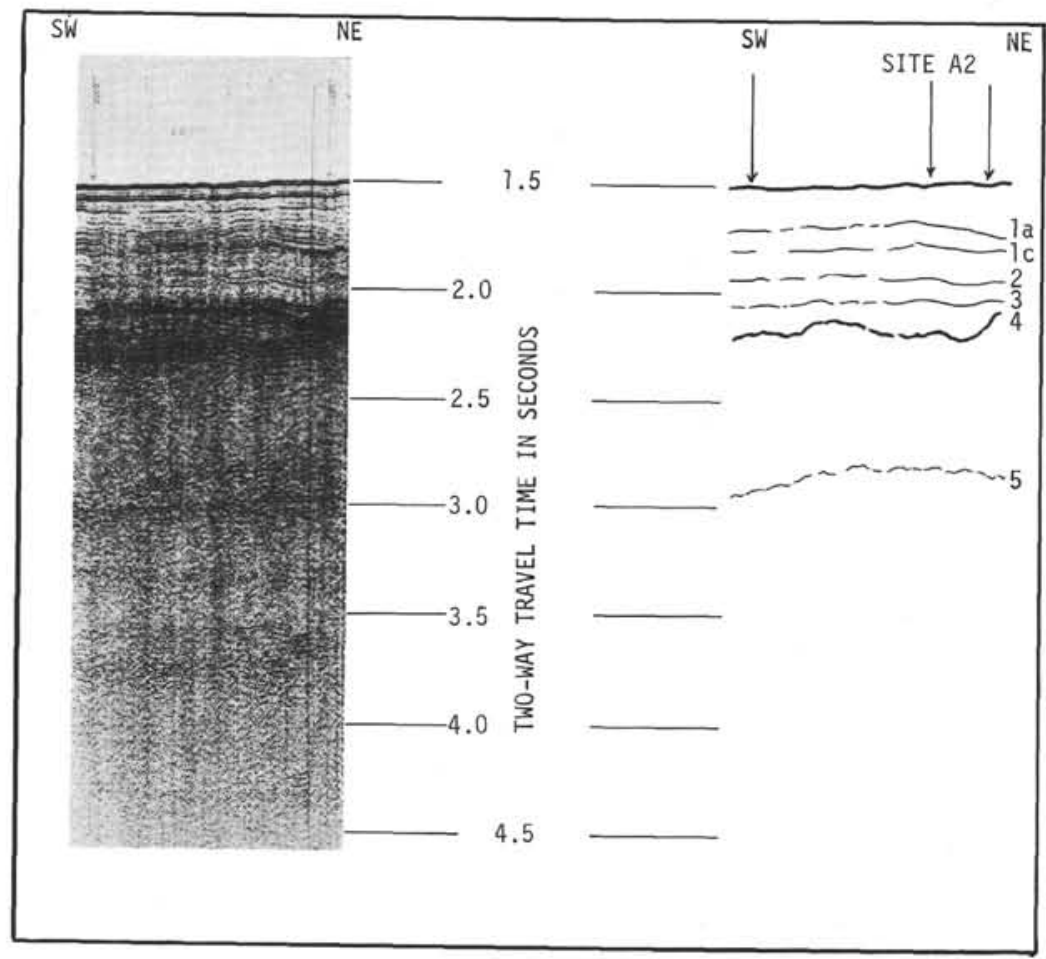

DISCOVERY CRUISE 29

$1600 / 249-2000 / 249$

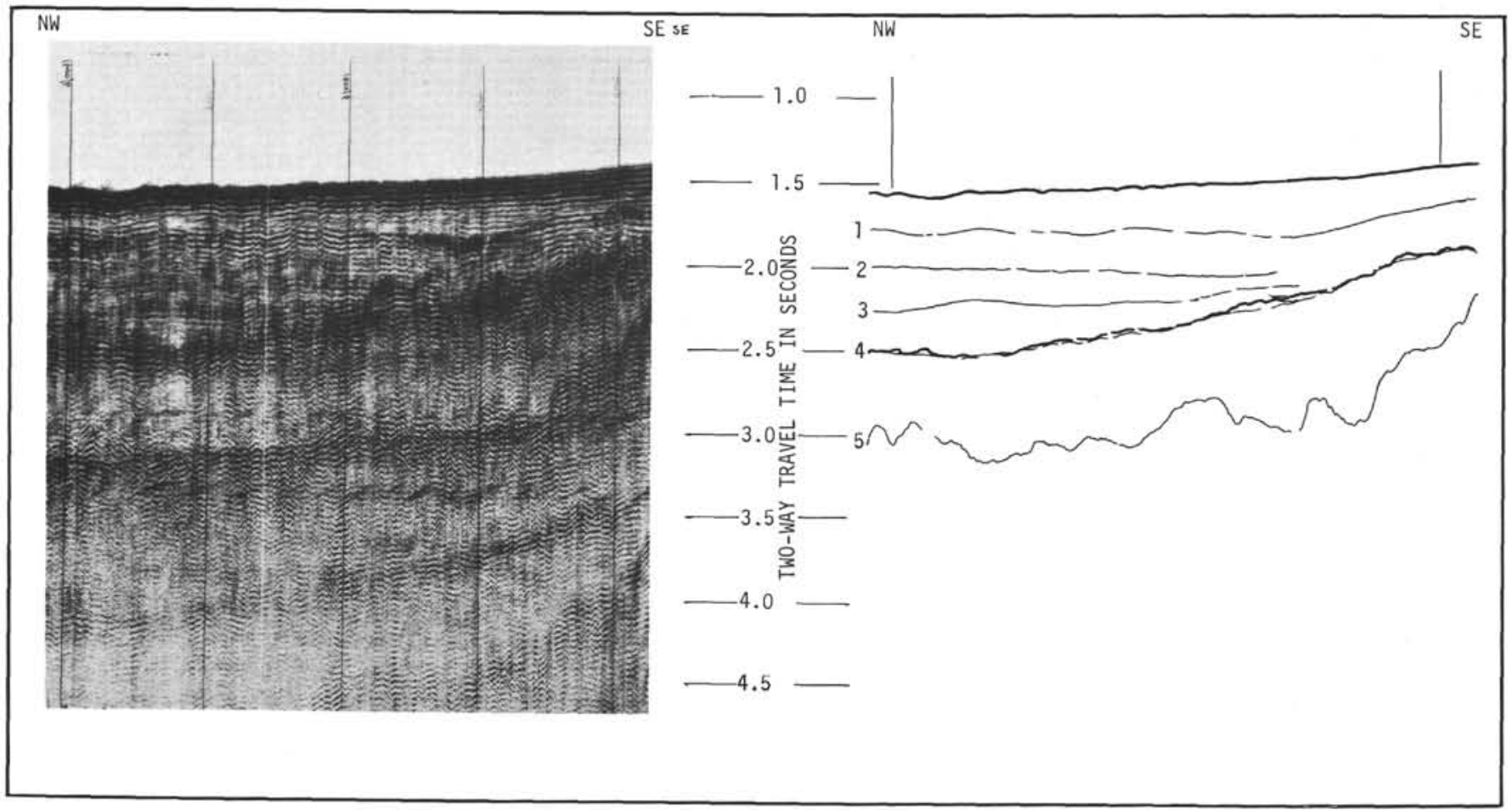

Figure 3. (Continued) 


\section{G. ROBERTS}

\section{Core Description}

The 3.79 meter gravity core consisted predominantly of calcareous lutites, calcareous ooze with occasional silty horizons. Coloring ranged from green-brown through brown to pale gray-white representing the purer calcareous oozes. An on board paleontological examination showed the core to be not older than Quaternary.

Figure 4 summarizes the shipboard description of core lithology. A more detailed description of the core is held at the National Institute of Oceanography and the core is archived at the Department of Environmental Sciences, University of East Anglia.

\section{SITE RECOMMENDATION}

Two sites were recommended to satisfy the maximum or minimum capability of the drilling ship. Additional criteria include the absence of faulting and unconformities in the layered sequence above reflector 4 . Site A1 is the preferred site.

\section{Site A 1}

$57^{\circ} 30.9^{\prime} \mathrm{N}, 15^{\circ} 55.3^{\prime} \mathrm{W}$.

\section{Site Survey Data}

$\begin{array}{ll}\text { Leg } 5 & -0047 \\ \text { Core } & -0.2 \mathrm{~nm} \text { distant } \\ \text { Fault } & - \text { None in immediate vicinity } \\ \text { Unconformity } & - \text { None } \\ \text { Depth to reflector } 4-0.81 \text { second (two-way time) }\end{array}$

Site A2

$57^{\circ} 29.6^{\prime} \mathrm{N}, 15^{\circ} 51.5^{\prime} \mathrm{W}$.

\section{Site Survey Data}

$\begin{array}{ll}\text { Leg } 7 & -0305 \\ \text { Core } & -3 \mathrm{~nm} \text { distant } \\ \text { Fault } & - \text { None } \\ \text { Unconformity } & - \text { Edge of unconformity in layered } \\ & \text { sequence }\end{array}$

Depth to reflector $4-0.75$ second (two-way time).

\section{REFERENCES}

Bullard, E. C., Everett, J. E. and Smith, A. G., 1965. The fit of the continents around the Atlantic. Phil. Trans. R. Soc. A. 242, 210.

Roberts, D. G., 1970. Recent geophysical studies on the Rockall Plateau and adjacent areas. Proc. Geol. Soc. London. 1662, 87.

Roberts, D. G., Bishop, D. G., Laughton, A. S., Ziolkowski, A. M., Scrutton, R. A. and Matthews, D. H., 1970. A newly discovered sedimentary basin on the Rockall Plateau. Nature. London, 225, 170.

Roberts, D. G., 1971. New geophysical evidence on the origins of the Rockall Plateau and Trough. Deep-Sea Res. $18,353$.

Scrutton, R. A. and Roberts, D. G., 1971. Structure of Rockall Plateau and Trough, North East Atlantic. In Geology of the East Atlantic Continental Margin. F. M. Delany (Ed.), London (Inst. Geol. Sci). Rept. 70/14, 77.
DISCOVERY STN. 7298

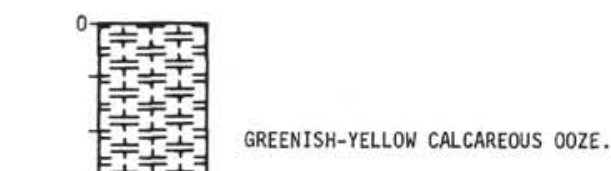

GREEN-BROWN CALCAREOUS SILTY CLAY. THIN OOZE HORIZON

GREEN-BROWN CALCAREOUS SILTY CLAY.

CALCAREOUS OOZE HORIZON.

GREENISH-BROWN CALCAREOUS LUTITE. BECOMING LIGHTER TOWARD BASE.

MOTTLED GRAY - GREEN CALCAREOUS LUTITE.

THIN CALCAREOUS OOZE.

GRAY -BROWN CALCAREOUS SILTY CLAY

PALE GRAY MARL.

THIN GREEN CALCAREOUS LUTITE.

PALE GRAY MARL.

PALE GRAY MARL GRADING DOWN INTO BROWN CALCAREOUS LUTITE.

PALE GRAY MARL.

PALE GRAY MRP

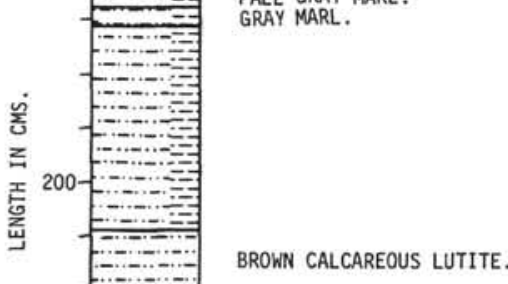

DARK BROWN CALCAREOUS SILTY LUTITE GRADING DOWN INTO DEEP RED BROWN CALCAREOUS SILTY LUTITE.

250
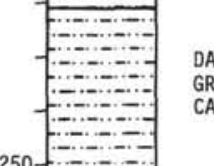

PALE GRAY BROWN LUTITE.

GREEN CALCAREOUS Lutite.

PALE GRAY CALCAREOUS MARL.

GREEN-BROWN CALCAREOUS LUTITE.

gRAY CALCAREOUS SILTY MARL.

GREEN CALCAREOUS LUTITE GRADING DOWN INTO REDDISH-BROWN SILTY-CLAY.

PALE GRAY MARL.

THIN GREEN CALCAREOUS LUTITE.

PALE GRAY MARL.

GRAY-BROWN LUTITE.

GRAY-MARL.

GREEN CALCAREOUS LUTITE WITH MACROFOSSIL FRAGMENT.

\section{.}

